Шило Ж. С., к.е.н., доцент (Національний університет водного господарства та природокористування, м. Рівне)

\title{
ОСНОВНІ НАПРЯМИ СТАБІЛІЗАЦІЇ БАНКІВСЬКОЇ СИСТЕМИ В УМОВАХ РИЗИКОВОЇ ЕКОНОМІКИ
}

У статті розглянуто економічну сутність поняття «стабільність банківської системи», визначені основні характерні ознаки стабільної банківської системи, наведені особливості та недоліки функціонування сучасної банківської системи, проаналізовані показники стійкості комерційних банків на прикладі вітчизняної банківської системи. Запропоновані напрями вдосконалення підвищення рівня стабільності банківської системи для забезпечення зростання економіки в цілому.

Ключові слова: стабільність банківської системи, комерційний банк, стійкість банківської установи, достатність капіталу, якість банківських активів.

Вступ. Стан і проблеми розвитку вітчизняної банківської системи традиційно викликають інтерес не лише фахівців з фінансовоекономічних питань і політиків, а й пересічних громадян, тим більше що з початком російської агресії проти України у 2014 р. загострилися застарілі фінансово-економічні кризові явища в державі. Це, у свою чергу, призвело до гострої кризи всієї банківської системи України, у результаті чого кількість комерційних банків скоротилася приблизно вдвічі. При цьому більшість комерційних банків в Україні виявилися фінансово збитковими. Проблеми банківського сектору гальмують розвиток підприємництва, сприяють занепаду виробництва, а згодом - призводять до економічного спаду в усіх сферах економіки. Тому виникає необхідність проведення дослідження та визначення напрямів стабільності банківського сектору, а також банківської системи в цілому для забезпечення фінансово-економічного зростання держави та її перехіду від збиткової до прибуткової діяльності.

Аналіз публікацій. Питання підвищення стабільності діяльності банківської системи $€$ широко досліджуваними. Розробкою методичних та практичних аспектів оцінки основних показників стабільності банківської системи займаються вітчизняні науковці. О. Дзюблюк, О. Вовчак, М. Савлук, А. Герасимович, О. Васюренко, А. Мороз, та за- 
рубіжні вчені: О. Лаврушин, К. Скіннер, М. Ротбард та інші.

Проте в умовах динамічності фінансово-економічних процесів проблематика забезпечення стабільності банківського сектору залишається невирішеною, постає потреба у розробленні рекомендацій щодо підвищення рівня стабільності банківської системи для забезпечення ії постійного економічного зростання.

Мета статті. Метою даного наукового дослідження $€$ проведення оцінки діяльності банківських установ в період нестабільності і ризикованості економічних перетворень та розроблення основних напрямів підвищення стабільності банківського сектора економіки держави. Дана мета обумовлює вирішення таких завдань:

- узагальнення теоретичних підходів до сутності поняття «стабільність банківської системи», та виявлення ознак, факторів впливу та елементів забезпечення стабільності банківської системи;

- проведення аналізу зовнішніх та внутрішніх факторів, які впливають на банківську систему, поточного стану банківської системи України та ефективності діяльності комерційних банків;

-- здіснення огляду існуючих методів стабілізації банківської системи на основі закордонного досвіду;

- визначення перспектив підвищення рівня стабільності банківської системи для забезпечення зростання економіки в цілому.

Основний розділ. Кожна держава світу зацікавлена у розвитку власної економіки. Основою економічних успіхів будь-якої держави $\epsilon$ фінансова стабільність, яка, у свою чергу, залежить від розвитку банківської системи. До трактування сутності поняття «стабільність банківської системи» підходять по-різному. Це викликано, зокрема, тлумаченням поняття «сутності», як незмінності чи тривалого збереження певного стану чи рівня розвитку.

Вітчизняні науковці О. В. Дзюблюк та Р. В. Михайлюк у своєму дослідженні підкреслюють, що стабільність банківської системи передбачає іï спроможність з плином часу забезпечити зменшення можливих втрат, належну швидкість їх подолання, створюючи тим можливості для досягнення та підвищення рівня стійкості [1, С. 29]. 3 точки зору В. Коваленко та Ю. Гаркуші під фінансовою стабільністю банківської системи слід розуміти міру повноти і якості вирішення завдань, поставлених перед нею, виконання банківською системою своєї місії, що забезпечує досягнення позитивного фінансового результату. Фінансова стабільність характеризує фактичний ступінь досягнення результату, заданого функцією системи [2, С. 128]. Цілком зрозуміло, що відсутній єдиний системний підхід до трактування сутності стабільності банківської системи. 
На наш погляд, під стабільністю банківської системи доцільно розуміти здатність забезпечувати та підтримувати рівноважний стан банківської системи та оперативно адсорбувати несподівані дії і шоки фінансової системи та реальної економіки. Розглядаючи фінансову стабільність банківської системи, потрібно враховувати притаманні їй ознаки, тобто особливості їі функціонування як в статичних умовах, так і під впливом зовнішніх шоків.

Можливо виділити певну сукупність ознак стабільної діяльності банківської системи. При виявленні таких ознак варто враховувати як кількісні (дотримання нормативних значень діяльності, вимог мінімізації ризиків та ін.), так і якісні характеристики функціонування банківської системи (рівень довіри, наявність стратегічних планів чи комплексів заходів щодо врегулювання діяльності та ін.).

Сутність стабільності банківської системи виявляється у процесі ефективного виконання поставлених перед нею завдань. До таких слід віднести: створення грошей та регулювання грошової маси країни; забезпечення ефективного розподілу фінансових ресурсів; забезпечення надійності і стабільності функціонування банківських установ з метою безперервного обслуговування економіки. Стабільною $€$ та банківська система, яка спроможна ефективно виконувати належні їй завдання та чітко виконувати свою роль в економіці держави, схильна до власного розвитку та реалізації свого потенціалу.

У процесі функціонування банківської системи виявляють ряд факторів, що мають вплив на ї̈ стабільність, роль і місце яких не можна недооцінювати. Фактори, що мають вплив на функціонування та стабільність банківської системи варто поділяти на зовнішні та внутрішні. До зовнішніх відносимо нормативно-правові, економічні та соціально-політичні фактори впливу. Внутрішні фактори, у свою чергу, $€$ підконтрольними банківській системі і впливають на їі стабільну діяльність більшою мірою, аніж зовнішні. До них належать організаційні, фінансово-економічні та технологічні. Простежимо дію зовнішніх факторів з точки впливу на стабільність банківської системи.

Для нормальної діяльності банківської системи, її продуктивного розвитку важливе значення має існування ефективної нормативно-правової бази, яка здатна дієво регулювати банківську діяльність загалом. Соціально-політичні фактори мають вплив на забезпечення стабільності банківської системи з огляду на впевненість населення у перспективах для розвитку економіки країни. Вони є важливими, адже формують рівень довіри клієнтів до банківської системи, їх готовності до здійснення банківських операцій та до користування різноманітними банківськими послугами. 
Щодо впливу внутрішніх факторів на стабільність банківської системи, то варто зазначити, що важливим у даній групі $є$ рівень менеджменту банківської установи. Від професіоналізму та ефективності керівництва окремої банківської установи може залежати розвиток усієї банківської системи. До наступної групи внутрішніх факторів, які забезпечують фінансову стабільність банківської системи, належать технологічні чинники. Вони охоплюють орієнтацію на розвиток передових банківських технологій, впровадження нових банківських продуктів і послуг та гарантують належний рівень інформаційної безпеки. І, звичайно, найбільш вагомий вплив на забезпечення стабільності банківської системи мають фінансово-економічні показники діяльності банківських установ: структура і обсяг власних коштів; якість активів; рівень ліквідності та платоспроможності.

Наступним кроком у дослідженні стабільності банківської системи $€$ визначення основних елементів її забезпечення. Елементи забезпечення - це сукупність чинників, засобів та заходів, що направлені на забезпечення стабільності банківської системи загалом. На наш погляд, варто виділити основні елементи забезпечення стабільності банківської системи:

1. Одним із найбільш вагомих елементів забезпечення стабільності банківської системи виступає пруденційний нагляд за банківською системою, що спрямований на забезпечення дотримання банками законодавства України і встановлених нормативів з метою уникнення кризових проявів в діяльності банківських установ.

2. Другим, не менш вагомим елементом $є$ правове та інформаційне регулювання банківської діяльності. Вважаємо, що розроблення нормативно-правових актів НБУ, формування системи стимулів і санкцій за порушення вимог законодавства, забезпечення захисту інтересів вкладників та кредиторів банку, а також формування системи захисту інформації покликані забезпечувати стабільність, запобігати відпливу депозитів, сприяти зміцненню довіри громадян до банківської системи.

3. Макроекономічне середовище держави, без сумніву, має опосередкований, однак надзвичайно вагомий вплив на дотримання стабільності роботи банківських установ. До нього відносимо стан платіжного балансу держави, інвестиційний клімат, стан реального сектору економіки, рівень тіньової економіки.

4. Важливим елементом $€$ здатність до власного розвитку та до реалізації свого потенціалу в діловому співробітництві на міжнародному ринку. Даний елемент залежить від позитивного макроекономічного середовища в державі; від наявності конкурентних переваг на ринку банківських послуг. Він характеризується впровадженням 
інформаційних технологій, високим рівнем банківського менеджменту.

5. Ще одним елементом $€$ фінансова стійкість банківських установ та банківської системи до розвитку та до реалізації свого потенціалу. Фінансова стійкість найбільш повно відображає усі негативні та позитивні тенденції розвитку банківської системи країни. Тому дослідженню основних показників фінансової стійкості банківських установ доцільно приділити значну увагу.

В умовах ризикової економіки однією з найпоширеніших проблем, пов'язаною із впливом фінансової кризи на діяльність банків, $\epsilon$ забезпечення фінансової стійкості українських банківських установ і банківської системи загалом та повернення ії стану на докризовий рівень.

На нашу думку, для оцінки фінансової стабільності банківських установ, необхідно проаналізувати динаміку основних показників їх діяльності за певний період часу. Фінансово стійким $€$ той банк, який має стабільний капітал, ліквідний баланс, вважається платоспроможним і задовольняє вимогам до якості капіталу.

1. Зростання статутного капіталу. В умовах дестабілізації фінансової, економічної та політичної ситуації в Україні через військові дії загострюються проблеми забезпечення національної безпеки в фінансовій та економічній сферах, у тому числі у банківській складовій. За 2015-2018 роки зросла частка іноземного капіталу в банківській системі України з 39,5\% до 48,1\%

За даними офіційного сайту Міністерства фінансів України станом на 01.01. 2019 року. кількість комерційних банків становила 77 (37 банків з іноземним капіталом і 22 - із 100\%-им іноземним капіталом та, відповідно, 40 вітчизняних банків, що склало 51,9\%)[3]. Негативною тенденцією в Україні $€$ те, що відбулось істотне скорочення за тими невеликими банками, де був представлений переважно вітчизняний капітал. 3 одного боку наявність банків з іноземним капіталом в Україні позитивно впливає на розвиток фінансової системи, адже сприяє залученню іноземних інвестицій. 3 іншого, велика частка іноземного капіталу призводить до відтоку українських банківських ресурсів за кордон, до обмеження доступу національних позичальників до внутрішніх заощаджень, а відтак - призводить до порушення фінансової стійкості вітчизняних банківських установ.

2. Достатність капіталу. У банківській системі серед основних показників діяльності банку, його розвитку та регулювання, головне місце займає показник достатності власного капіталу, або капітальної адекватності масштабам і характеру здійснюваних банком опе- 
рацій. Достатня величина власного капіталу має бути основою для захисту інтересів як вкладників, так і кредиторів, а також гарантією покриття збитків від банківських операцій. Аналіз достатності власного капіталу наведемо у таблиці 1.

Таблиця 1

Динаміка капіталу комерційних банків за 2016-2019pр. (млн грн.)

\begin{tabular}{|l|c|c|c|c|}
\hline \multicolumn{1}{|c|}{ Показники } & $\begin{array}{c}01.01 . \\
2016\end{array}$ & $\begin{array}{c}01.01 . \\
2017\end{array}$ & $\begin{array}{c}01.01 . \\
2018\end{array}$ & $\begin{array}{c}01.01 . \\
2019\end{array}$ \\
\hline Капітал & 103713 & 123784 & 161108 & 149400 \\
\hline $\begin{array}{l}\text { у тому числі } \\
\text { статутний капітал }\end{array}$ & 222170 & 414668 & 495377 & 465038 \\
\hline Регулятивний капітал & 129817 & 109654 & 1115817 & 126117 \\
\hline $\begin{array}{l}\text { Норматив достатності } \\
\text { регулятивного капіта- } \\
\text { лу }\end{array}$ & 12,31 & 12,69 & 16,10 & 16,18 \\
\hline
\end{tabular}

Аналізуючи дані таблиці бачимо, що величина капіталу комерційних банків у 2019 році порівняно із 2018 р. знизилась на 11,7 млрд грн. Такі негативні тенденції пов'язані насамперед із результатами діяльності та докапіталізацією Приватбанку, а також із зменшення прибутковості роботи банків у зв'язку із девальвацією національної валюти, збільшенням валютних зобов'язань, зменшенням чистих процентних доходів.

Вагомий вплив на стійкість банківської установи має регулятивний капітал, основне призначення якого полягає у покритті негативних наслідків різноманітних ризиків. Обсяг регулятивного капіталу станом на початок 2019 р. порівняно із 2016 р. зменшився на 3,7 млрд грн. Таке скорочення зумовлене, насамперед, переведенням комерційних банків у стан ліквідації та певними збитками, які були отримані внаслідок формування резервів. Але протягом 2017-2018 рр. спостерігаємо незначне нарощення регулятивного капіталу, яке, у свою чергу, дозволило покращити значення нормативу достатності регулятивного капіталу (Н2). Цей показник зріс протягом 2017-2018 pp. $312,69 \%$ до $16,10 \%$, що говорить про виконання банками програм докапіталізації. Збільшення обсягу регулятивного капіталу, $є$ безпосереднім доказом підвищення можливості забезпечення захисту вкладів та фінансової стійкості банківської діяльності.

3. Якість банківських активів. В процесі фінансової діяльності банку необхідно проводити комплексну оцінку формування його ресурсів та напрями їх розміщення. Тому одним з головних напрямів комплексного фінансового аналізу банківської діяльності щодо відповідності критеріям стійкості $€$ аналіз активних операцій. Активи 
українських діючих банків, без урахування неплатоспроможних банків, у 2018 році становили 1,320 трлн грн. Найвищу позицію у рейтингу найбільших банків за величиною активів займають Приватбанк (розмір активів склав 230953162 тис. грн.), Ощадбанк (220722793 тис. грн.) та Укрексімбанк (168366915 тис. грн.) [4]. Основна складова приросту загальних активів - збільшення портфеля ОВДП України та похідних інструментів Приватбанку внаслідок його переходу до державної власності, а також перегрупування структури власності, збільшення частки активів державних та системних банків, рефінансування проблемних державних банків з метою зміцнення їх позицій.

За останні роки простежується динаміка до збільшення загальної суми наданих кредитів (табл. 2).

Таблиця 2 Обсяг та структура кредитного портфеля комерційних банківУкраїни за 2016-2019 рр. (млрд грн.)

\begin{tabular}{|l|c|c|c|c|}
\hline \multicolumn{1}{|c|}{ Показники } & $\begin{array}{c}01.01 . \\
2016\end{array}$ & $\begin{array}{c}01.01 . \\
2017\end{array}$ & $\begin{array}{c}01.01 . \\
2018\end{array}$ & $\begin{array}{c}01.01 . \\
2019\end{array}$ \\
\hline Кедити надані & 1116 & 1025 & 1078 & 1182 \\
\hline $\begin{array}{l}\text { Кредити юридичним осо- } \\
\text { бам }\end{array}$ & 847 & 848 & 865 & 941 \\
\hline Кредити фізичним особам & 155 & 157 & 171 & 209 \\
\hline Міжбанківські кредити & 114 & 20 & 42 & 38 \\
\hline
\end{tabular}

Проводячи аналіз показників наведених в таблиці видно, що станом на січень 2019 року порівняно з попереднім періодом відбулось збільшення кредитування як юридичних так і фізичних осіб відповідно на 8,8\% та 12,2\%. У споживчому сегменті збільшення попиту зумовили декілька факторів: зниження кредитних ставок, покращення споживчих настроїв і скорочення заощаджень домогосподарств. Також з таблиці 2 бачимо, що у 2018 році порівняно з 2016 роком обсяг наданих міжбанківських кредитів значно скоротився (на 33,4\%), що свідчить, у свою чергу, про відновлення стабільності банківської системи, підвищення платоспроможності окремих банків та збільшення показників ліквідності.

Великий вплив на проблему стійкості банківської установи на даний момент має нагромадження великих обсягів непрацюючих кредитів у структурі кредитного портфеля усіх банків. Обсяг проблемних кредитів у кредитному портфелі банків $€$ основним показником його якості. Протягом 2016-2018рр. зберігалась тенденція щодо погіршення якості кредитного портфеля банків. Згідно з даними НБУ станом на 01.01.2016 року питома вага проблемних кредитів сягала 
$22,1 \%$. Проте вже у на кінець 2017 року становила 55,75\%. Водночас треба підкреслити, що активізація кредитної діяльності українських банків потроху поліпшує стан їхнього кредитного портфелю, що виражається в скороченні частки непрацюючих кредитів. Так, за інформацією ЗМІ з посиланням на дані НБУ, українські банки скоротили частку проблемних непрацюючих кредитів на 0,6 в. п. - до 55,1\% за підсумками липня 2018 р. Скорочення частки проблемних кредитів відбулося за всіма групами банків, крім банків з приватним капіталом: у державних банках - до 59,1\%, іноземних банках - до 41,8\%, у ПриватБанку - до 84,5\%. У банках з приватним капіталом цей показник зріс на 0,5 в. п. - до 24,6\%. I хоча темпи скорочення таких кредитів невисокі, але Міжнародне рейтингове агентство Moody's очікує скорочення частки проблемних кредитів в українських банках до 45$50 \%$ до кінця 2018 р. [5].

4. Динаміка депозитних операцій банку. У період піку фінансовоекономічної кризи український банківський сектор зіткнувся з небаченим раніше за масштабами відтоком депозитних коштів з рахунків банків. Так, наприкінці 2014 р. голова НБУ заявила, що відтік депозитів у банківській системі за рік досяг 126 млрд грн., тобто близько $29 \%$ депозитів фізичних осіб. Починаючи з 2016 року відбувається незначний притік депозитних коштів фізичних та юридичних осіб. За 2018 рік депозити населення у гривні зросли на 10,8\%, у валюті - не змінилися. Депозити корпорацій зросли на 8,9\% у порівнянні з 2017 роком, що є позитивним фактором для стабілізації банківської системи в цілому.

5. Структура доходів і витрат банківської установи. Важливим показником стійкості банківської установи $€$ отримання прибутків від своєї діяльності. Тому характерною ознакою нинішнього етапу розвитку української банківської системи $€$ перехід від збиткової до прибуткової роботи. Зокрема, в січні - липні 2018 року сукупні доходи комерційних банків України становили 108,9 млрд проти 101,6 млрд грн. за січень - липень минулого року. Витрати ж комерційних банків України за цей період скоротилися зі 101,8 млрд до 99,1 млрд грн. У результаті за січень - липень 2018 р. українські комерційні банки в цілому отримали сукупний прибуток у обсязі 9,7 млрд проти 223 млн грн. збитку за аналогічний період 2017 р. При цьому зростання прибутковості комерційних банків в Україні пов'язане зі скороченням їхніх витрат на резерви, як у структурі витрат банків з $21 \%$ за перші сім місяців 2017 р. до $11,7 \%$ у січні - липні 2018 р., так і в абсолютному вимірі - 321,4 млрд до 11,6 млрд грн. у зазначені періоди. Слід зазначити, що зростання сукупних доходів комерційних банків України у січні - липні 2018 року, порівняно 3 
аналогічним періодом минулого року, викликане збільшенням як процентних доходів (з 71,3 млрд до 78 млрд грн.), так і комісійних (з 21,2 млрд до 28,3 млрд грн.). Також відмітимо, що прибутки всієї системи українських комерційних банків концентрувалися насамперед у найбільших банках. Зокрема, найбільші 25 українських банків (за розміром чистих активів) за підсумками своєї комерційної діяльності у січні - червні 2018 р. отримали сукупний чистий прибуток у розмірі 7,5 млрд проти 1,7 млрд грн сукупного збитку за аналогічний період 2017 р. [4].

Аналіз наведених вище даних свідчить, що більш радикальний перехід від збиткової до прибуткової діяльності відбувався саме у великих комерційних банках України. Це, на наш погляд, пов'язано зі значно більшими можливостями саме великих комерційних банків у сфері надання різноманітних фінансових послуг як підприємствам, так і населенню (домогосподарствам). Тому поліпшення економічної ситуації в Україні, що спостерігається останнім часом, позитивно позначилося на роботі насамперед великих банківських установ.

Висновки. Підсумовуючи виконання поставлених завдань нашого наукового дослідження відзначимо, що у функціонуванні банківських установ виявлено ряд недоліків та проблем.

Зокрема, актуальними залишаються такі: низький рівень капіталізації банків, який обмежує можливості банків щодо нарощування обсягів кредитування, в першу чергу, тоді, коли економіка потребує вагомої фінансової підтримки; невисока якість активів. Зважаючи на те, що основною частиною активів є кредитні вкладення, то відповідно значно зростають кредитні ризики; постійний дисбаланс у структурі активів і пасивів, що веде до пониження рівня банківської ліквідності; непостійного рівня прибутковості банків.

До найбільш дієвих та ефективних способів розв'язання проблемності банківських установ, на нашу думку, слід віднести наступнi:

- розробка плану реструктуризації банку - комплекс заходів, які застосовуються державою для урегулювання проблем, які виникають під час кризи;

- рефінансування центральним банком (НБУ) - як спосіб підвищення фінансової стійкості банківського сектора, а також стабілізації діяльності банківських установ, що зазнають фінансові труднощі [ 6 ];

- злиття з іншим банком або поглинання іншим банком (у міжнародній практиці цей метод має- купівля банку з прийняттям зобов'язань або поступова ліквідація;

- націоналізація проблемного банку державою. 
Однак запропоновані заходи не сприятимуть стабілізації банківської системи без покращення інвестиційного клімату в країні, реформування судової системи, посилення заходів щодо ліквідації корупції. Стабільне функціонування банківської системи має зумовити перехід на якісно новий рівень фінансового регулювання і нагляду та забезпечити підвищення стабільності фінансово-кредитної системи в цілому.

1. Дзюблюк О. В. Фінансова стійкість банків як основа ефективного функціонування кредитної системи : монографія. Тернопіль : Тернограф, 2009. 316 с. 2. Віннічук Ю. Наскільки зросли вклади населення в банках. URL: https://biz.censor.net.ua/resonance/3026108/nasklki_zrosli_vkladi_nas elennya_v_bankah. (дата звернення: 15.03.2019). 3. Офіційний сайт Міністерства фінансів України. URL: http://index.minfin.com.ua/bank/stat/. (дата звернення: 15.07.2019). 4. Офіційний сайт Національного банку України. URL: https:// www.bank.gov.ua/control/uk/index. (дата звернення: 15.03.2019). 5. Рейтинг найнадійніших банків України 2018. URL: https://forinsurer.com/ rating-banks (дата звернення: 15.03.2019). 6. Рішення Ради НБУ Про діяльність Правління Національного банку України щодо розвитку банківської системи та окремих нормативних актів. URL: https://bank.gov.ua/control/uk/ publish/category. (дата звернення: 15.03.2019). 7. Яремчук О. В. Аналіз достатності власного капіталу банку. Фінансово-кредитна діяльність: проблеми теорії та практики. 2016. № 1. URL: http://fkd.org.ua/article/view/29107/26232. (дата звернення: 15.03.2019).

\section{REFERENCES:}

1. Dziubliuk 0. V. Finansova stiikist bankiv yak osnova efektyvnoho funktsionuvannia kredytnoi systemy : monohrafiia. Ternopil : Ternohraf, 2009. 316 s. 2. Vinnichuk Yu. Naskilky zrosly vklady naselennia $v$ bankakh. URL: https://biz.censor.net.ua/resonance/3026108/nasklki_zrosli_vkladi_naselenn ya_v_bankah. (data zvernennia: 15.03.2019). 3. Ofitsiinyi sait Ministerstva finansiv Ukrainy. URL: http://index.minfin.com.ua/bank/stat/. (data zvernennia: 15.03.2019). 4. Ofitsiinyi sait Natsionalnoho banku Ukrainy. URL: https:// www.bank.gov.ua/control/uk/index. (data zvernennia: 15.03.2019). 5. Reitynh nainadiinishykh bankiv Ukrainy 2018. URL: https://forinsurer.com/ rating-banks (data zvernennia: 15.03.2019). 6. Rishennia Rady NBU Pro diialnist Pravlinnia Natsionalnoho banku Ukrainy shchodo rozvytku bankivskoi systemy ta okremykh normatyvnykh aktiv. URL: https://bank.gov.ua/control/uk/ publish/category. (data zvernennia: 15.03.2019). 7. Yaremchuk 0. V. Analiz dostatnosti vlasnoho kapitalu banku. Finansovo-kredytna diialnist: problemy teorii ta praktyky. 2016. № 1. URL: http://fkd.org.ua/article/view/29107/26232. (data zvernennia: 15.03.2019). 
Shylo Z. S., Candidate of Economics (Ph.D.). Associate Professor (National University of Water and Environmental Engineering, Rivne)

\section{MAIN DIRECTIONS OF STABILIZATION OF THE BANKING SYSTEM UNDER RISK ECONOMY}

The introduction examines the economic essence of the notion of "stability of the banking system", as well as the necessity of conducting research and determining the directions of stability of the banking sector of the economy. The purpose of this scientific research is to evaluate the activities of banking institutions in the period of manifestation of crisis phenomena and to develop the main directions for increasing the stability of the banking sector of the state economy. The article defines the main characteristic features of a stable banking system, the identification of which should take into account both quantitative (observance of normative values of activity, requirements for minimization of risks, etc.), as well as qualitative characteristics of the functioning of the banking system (level of trust, the availability of strategic plans or sets of measures for regulation activities, etc.). In particular, the following remain relevant: low level of capitalization of banks, which limits the ability of banks to increase lending volumes, first of all, when the economy needs significant financial support; low asset quality. Considering that the main part of assets is credit investments, then correspondingly significant credit risks increase; constant imbalance in the structure of assets and liabilities, which leads to a decrease in the level of bank liquidity; inconsistent level of profitability of banks. The indicators of stability of commercial banks are analyzed on the example of the domestic banking system. The directions of improving the level of stability of the banking system to ensure the growth of the economy as a whole are proposed. Consequently, the stable functioning of the banking system should lead to the transition to a qualitatively new level of financial regulation and supervision and to ensure the stability of the financial and credit system as a whole.

Keywords: stability of the banking system, commercial bank, stability of the banking institution, capital adequacy, quality of banking assets. 
Шило Ж. С., к.э.н., доцент (Национальный университет водного хозяйства и природопользования, г. Ровно)

\section{ОСНОВНЫЕ НАПРАВЛЕНИЯ СТАБИЛИЗАЦИИ БАНКОВСКОЙ СИСТЕМЫ В УСЛОВИЯХ РИСКОВАНОЙ ЭКОНОМИКИ}

В статье рассмотрено экономическую сущность понятия «стабильность банковской системы», определены основные характерные признаки стабильной банковской системы, приведены особенности и недостатки функционирования современной банковской системы, проанализированы показатели устойчивости коммерческих банков на примере отечественной банковской системы. Предложены направления совершенствования повышения уровня стабильности банковской системы для обеспечения роста экономики в целом.

Ключевые слова: стабильность банковской системы, коммерческий банк, устойчивость банковского учреждения, достаточность капитала, качество банковских активов. 